\title{
The Role of Network Ties on SMEs Internationalization Process in the Developing Countries/Emerging Markets: A Comparison between Mongolia, China, and Malaysia
}

Submitted 02/12/20, $1^{\text {st }}$ revision 12/01/21, $2^{\text {nd }}$ revision 22/02/21, accepted 20/03/21

\author{
Ulziimaa Altnaa ${ }^{1}$, László Vasa ${ }^{2}$, György Iván Neszmélyi ${ }^{3}$
}

\begin{abstract}
:
Purpose: The paper aims to investigate the role of all types of networking on SMEs' internationalization process in general. Then, to compare SMEs' networking approaches in the selected three countries and their main differences in terms of network creation and operation. Finally, to report effective SMEs' internationalization practices in Malaysia and China, which should be adopted in Mongolia.

Approach/Methodology/Design: The study is descriptive and used secondary data as the primary source. We concluded institutional networking substituted by the social and business networking ties in developing countries such as China, Malaysia, and Mongolia.

Findings: These SMEs rely heavily on the information collected by the personal channels to bring about both pros and cons for their internationalization process. Secondly, the policymakers should establish the private specialized firms or export agencies established in Malaysia and China a long time ago to address information and knowledge barriers faced by SMEs in Mongolia.

Practical Implications: The first implication is SME managers or owners in developing countries prefer to have strong social relationships with actors, which help them to receive some benefits and accelerate their internationalization process, but it results in neglecting institutional networking some crucial roles.
\end{abstract}

Keywords: Network ties, Small and Medium-Sized Enterprises (SMEs), internationalization, Malaysia, China, Mongolia.

JEL classification: $F 23$, L25, R12

Paper type: Research paper.

LCC: HD2709-2930.7

\footnotetext{
${ }^{1}$ Ph.D., Budapest Business School, Hungary, Ulziimaa.Altnaa.28@unibge.hu

${ }^{2}$ Prof. Széchenyi István University, Hungary and Institute for Foreign Affairs and Trade,

Hungary, laszlo.vasa@ifat.hu

${ }^{3}$ Prof. Budapest Business School, Hungary, Neszmelyi.Gyorgy@uni-bge.hu
} 


\section{Introduction}

In the modern world, small and medium-sized enterprises (SMEs) have long been recognized as significant contributors to economic development both in developed and developing countries (Hashim, 2015, Solongo, 2017, Puthusserry et al., 2020) because they generate economic growth, create job opportunity, advance technological capability, diversify products, and tax revenues, and assist in alleviating poverty and income inequality based on their limited resources, especially, in developing and emerging markets (Arudchelvan and Wignaraja, 2015). Also, it is proven that SMEs are closely linked in the gross domestic product (GDP) and export increase, and most of the registered enterprises in both developed and developing countries fall in the category of SMEs. Globally, SMEs account for more than 90 percent of all business (Doojav et al., 2020), over 90\% of the total business enterprises are classified as SME in East Asia (Abdullah and Zain, 2011), and in Malaysia, 90\% of total enterprises are SMEs contributing to over $33 \%$ of the GDP, respectively (Hashim, 2015). Whereas in China, SMEs account for $97.33 \%$ of all the registered enterprises and contribute more than $60 \%$ of China's GDP (Deng and Zhang, 2018), and in Mongolia, $98 \%$ of total actively operating firms were SMEs and contributed $17.8 \%$ of GDP in 2017 (Doojav et al., 2020).

Besides the brief theoretic overview, the authors examine, based on secondary research (bibliographic process and data analysis), the practices of three Asian countries in terms of state and prospects of SMEs with the view of drawing and collecting adoptable acceptable practices, principally Mongolia. However, perhaps some of the results of the research can be utilized in Hungary as well.

In the past few years, the trade liberalization and globalization of the world market have been taking place intensively. It brings either opportunities or risks for all different kinds of enterprises, including SMEs (Vásáry et al, 2013; Lis et al., 2012; Karácsony, 2020). Many multinational enterprises (MNEs) chose emerging markets, China, India, and Eastern Europe, as their next target to enter and gain profit. One of the main risks that come up with globalization is the entry of international players into the domestic market, bring about saturation on the market to a great extent, and the domestic SMEs lose their competitive advantages if there is not any strict rule imposing to support domestic SMEs from the governmental side (Lloyd and Mughan, 2002; Lis et al., 2012).

Therefore, internationalization appears to be a solution for the SMEs in developing countries, particularly countries with small domestic markets and exist in the region easy to enter for other MNEs, growth, and survival (Jeong, 2016; Costa et al., 2017; Ahimbisibwe et al., 2020). Lis et al. (2012) pointed out that internationalization is the outward process of entering into a new geographical location and expanding their operations in the international field. On the bright side of the globalization phenomenon is the encouragement for large enterprises and SMEs to expand their business beyond the domestic market and compete globally with fewer barriers 
The Role of Network Ties on SMEs Internationalization Process in the Developing

Countries/Emerging Markets: A Comparison between Mongolia, China, and Malaysia

(Chelliah et al., 2010; Abdullah and Zain, 2011). It also helps reveal their capabilities and develop an entrepreneurial orientation for the owner-managers to enhance their competitive advantage in a rapidly changing environment and be competent enough for aggressive competition (He et al., 2020).

Ahimbisibwe et al. (2020) specified that compared SMEs in developing countries to MNEs possess a limited resource, market knowledge, and skills. Thus, SMEs in developing countries will promote their international participation by enabling their network with other foreign market actors. At the same time, Nyuur et al. (2018) pointed out a positive association between network ties on SMEs' performance. Numerous studies have shown that the network contributes significantly to SMEs' internationalization and the three types of networks- social networking, business networking, and institutional networking- play different roles in this phenomenon. In the initial stages of internationalization, social networks have a more considerable influence, while business networks become more relevant in subsequent stages, and then institutional networks have a positive impact on the internationalization of SMEs as well (Costa et al., 2017; Nyuur et al., 2018; Sokil et al., 2018; Hao et al., 2020).

Malaysia's Southeast Asia location sets off an essential advantage for local SMEs involved in the global market. Southeast Asia - the ASEAN region - is nowadays a highly competitive economic region in the world with a combined GDP of USD 2.6 trillion in 2014 (Kozár and Neszmélyi, 2017). Additionally, governmental actions to support SMEs internationalization, political stability, a first-class physical infrastructure, and human resource fond play a vital role for enterprises in Malaysia shifting their focus from the domestic market to the international market (Senik et al., 2010). The previous studies had been done on the internationalization of the SMEs in Malaysia show that SMEs contributes to the local economy by creating job opportunity, bringing new technological innovation and advancement, and resulting in rapid economic growth (Chelliah et al., 2010; Abdullah and Zain, 2011; Hashim, 2015; Magda and Dhanashree, 2017). In Malaysia, SMEs account for 33\% of GDP and $18 \%$ of the total export and create $60 \%$ employment. In sum, 19 ministries and 21 governmental agencies engaged in establishing and implementing SME policies, through which 123 programs were developed to support SMEs' internationalization process (Abdullah and Zain, 2011). Over the last years, thousands of SMEs and MNEs in China have been successfully drawn into the international market (Sandberg and Jansson, 2014). Since the Inauguration of market reform in 1978, China has experienced economic growth at a substantial rate.

Along with economic growth, the number of SMEs increased significantly. SMEs play a significant role in the second-largest economy globally, and as of 2013,97.33\% of all registered enterprises were SMEs, contributing higher than $60 \%$ of GDP. This prosperity of SMEs in China is considered a result of the government policies, partially (Sandberg and Jansson, 2014; Deng and Zhang, 2018, Ishtiaq et al., 2018). 
Unlike Malaysia and China, the Mongolian economy is massively linked with the resource sector accounting for $90 \%$ of total export and $25 \%$ of budget revenue. Mongolia has certain advantages such as open economic environment, the vast territory and pastures, and large quantity of livestock, rich natural resources, two large neighbour markets and possibility of reaching out to the rapidly developing markets in the Asian-Pacific Region (Neszmélyi 2002). The experts highlighted a massive need for diversifying the economy by supporting SMEs development (Narain, 2013; Doojav et al., 2020). Although SMEs generate relatively low levels of value-added products or services and exports in Mongolia, they dominate the economy in terms of magnitude and employment. As of 2019, SMEs provide $67 \%$ of the total job opportunity, produce $20 \%$ of GDP, and generate $2.3 \%$ of total export (Lkhagvasuren, 2014). Compared to other countries, both Malaysian and Mongolian SMEs have contributed less amount of share in export, $18 \%$ and $2.3 \%$, respectively, as Germany recorded $57 \%$ share, Italy $36.7 \%$, Taiwan $31.4 \%$, China $68 \%$, Japan $20.3 \%$, and the Republic of Korea 16\% (Yener et al., 2014).

Although influential factors for SMEs internationalization have been studied substantially in the last three decades in the literature, empirical studies focusing on networking in SMEs internationalization, especially the role of networking capabilities to SMEs internationalization phenomenon in developing countries, are still insufficiently studied. Therefore, doing this study, we contribute limited knowledge in SMEs' internationalization in developing countries. In the first section, an introduction is presented. The literature review is shown in the second section. This is followed by section three, which provides an idea of network ties on SMEs internationalization from the networking perspectives. Then, section four depicts the methodology. Finally, section five presents the result, and section six shows the conclusions and implications of the study.

\section{Theoretical Framework}

In past years, researchers have been studying the internationalization phenomenon based on several different theories and perspectives, and most cited internationalization theories and perspectives, the Uppsala model, the Networking perspective, and the International New Ventures - also known as Born Global- have influenced research on SME internationalization are highlighted in this section (Senik et al., 2010).

\subsection{Uppsala Model}

The Uppsala model, one of the most utilized internationalization theories, was developed by Johanson and Wiedersheim-Paul at first and then to be enriched by Johansen and Vahlne (Senik et al., 2010; Lis et al., 2012, Gardó et al., 2015). In this theory, the researcher emphasized that SMEs gradually internationalize via many stages using two different approaches instead of becoming a full player from the beginning (Lis et al., 2012). International activities, such as exports, are a means 
The Role of Network Ties on SMEs Internationalization Process in the Developing

Countries/Emerging Markets: A Comparison between Mongolia, China, and Malaysia

which generates growth for small businesses, make value, and acquire new knowledge and technologies from abroad (Bowen, 2019). The first approach is the four stages of the foreign entry process starting from no constant export activity to export their products with the help of independent representative or agents, after then to establish their own sales subsidiaries, in the final stage, the firm begins to produce or manufacture their products in the new market.

This approach is considered as the low risk and low commitment strategy at the starting point because exporting does not require a high amount of financial capital, resource, and skills, and the firm may continuously adopt a high risk and high commitment strategy eventually. The second approach is slightly different from the first approach by choosing entry mode as a new geographical area, which is the less psychic distant market regarding language, education, business practices, culture, and industrial development. This approach recommends that firms enter a new market adjacent to and identical to the home country before spreading to more remote and dissimilar markets (Senik et al., 2010; Costa et al., 2017; Bowen, 2019). The Uppsala model notices the internationalization process as the incremental and gradual pattern that firms enter a new market first, which can be either a distant physical market or a less physical distant market and acquire experience and later expand their activities through establishing their subsidiaries, joint ventures, and acquisitions (Abdullah and Zain, 2011; Lis et al., 2012; Solongo, 2016).

\subsection{Born Global or the International New Venture (BG/INVs)}

As a positive consequence of rapid globalization and technological advancement, the number of firms interested in participating in the international market increased significantly (Abdullah and Zain, 2011). In such a manner, a high increase in the number of SMEs came up with new types of firms that can skip stages of the gradual internationalization model. Oviatt and McDougall (1994) pointed out that these types of firms are called International New Venture (INVs), also known as Born Global firms (BG), which progress is skipping the stage theory of internationalization, the Uppsala model, from the initial stage. The main focal point of the INVs model is age, and it proposes the INVs to gain significant comparative advantages from the beginning of establishment by utilizing their resources and the sale of products in several different markets (Senik et al., 2010; Lin et al., 2016; Ahimbisibwe et al., 2020).

BG/INVs skip stages of incremental internationalization when doing business and are involved in the international activities within the first year of establishment or a few years from inception (Senik et al., 2010; Bowen, 2019). Abdullah and Zain (2011) argue that there are no single exact periods, which is determined the starting date of their international operations and earning profit for Born Global/ INVs. Some research defined Born global/INVs start their business operation within the first two years after the establishment (Senik et al., 2010), while some stated INVs/Born global 
start their international operations and earn much of their profit within six years of establishment. Rennie (1993), Knight, and Cavusgil (1996) stated that INVs/BG are firms whose internationalization process is to be taken within three years from inception, and they generate at least $25 \%$ of sales from export within this period. While et al. (2016) indicate that BG/INVs in developing countries or the emerging markets might have different influential factors for their establishment and further progress than those in developed countries because of environmental parameters and market context.

\subsection{The Network Theory}

Johanson and Mattson (1998) describe how the network influences as a catalyst for SME's steady growth in the internationalization phenomenon (Senik et al., 2010). The term network refers to all kinds of interrelationships of SMEs with the actors involving in the market, including individuals, institutions, other businesses, customers, specific communities, and government agencies (Senik et al., 2010; 2011). Afsharghasemi et al. (2013) concurred that firms' relationships could be either form of collaborative associations with competitors or a voluntary agreement between firms. Previous research largely agreed that with the help of networking, all actors engaged in the market could benefit from their internationalization process; thereby, it is not an individual or sole effort that needs to be taken (Afsharghasemi et al., 2013; Ahimbisibwe et al., 2020). Musteen et al. (2010) argue that SMEs have several different characteristics because of their limited resources and market power, compared to the multinational enterprises (MNEs) when they track the new opportunities in the international market. One of them is their dependency upon the network ties to a great degree. Through the network they possess, the firms get hold of resources to enhance their strategic posture, to manage transaction costs, to acquire new knowledge and skills, to lessen entry barriers, and to overcome rapid technological challenges that might occur (Senik et al., 2011; Abdullah and Zain, 2011; Hashim, 2015; Costa et al., 2017).

According to Senik et al. (2010) and Torkkeli et al. (2012), networking could overcome size problems, develop strategic plans to speed up their internationalization process, engage with a born-global pattern, ensure survival in the long run, build international contacts, and find suitable agents. Systematically, the firm learns and accumulates experiential knowledge by running a business in the international market in the first few years and then fully internationalizes gradually (Sandberg and Jansson, 2014). In this theory, Johanson and Mattsson (1988) stated that the full internationalization process comes about because of three interdependent stages of establishing network posture within the foreign market: the first stage, also known as the network extension stage. The second stage is network penetration, which means those relationships in the networks are to be developed and coordinated in different countries, named the network integration stage (Ahimbisibwe et al., 2020). 
Network types are often classified into social, business, and institutional networks (Jeong, 2016; Costa et al., 2017). Jeong (2016) defined the types of the network as follows; the social network is a network that is evolved from personal connections and represented by individuals, family, friends, colleagues, and employees; the business network is developed based on mutual agreement between actors participating in a shared resource exchange to reach a common shared goal through cooperation. Simultaneously, Costa et al. (2017) argue that an institutional network is developed with actors including governments, incubators, research institutes, agencies for international development, and business associations. In this study, discussion of the role of networking in SMEs internationalization process, how these roles relate to institutional supports, and how network contributes SMEs in developing countries internationalization is what this paper seeks to do are reviewed.

\section{A Key Role of Networking on Internationalization of SMEs}

As stated in the former two sections, the network has long been acknowledged as an essential factor to SMEs internationalization phenomenon due to almost all small and medium-sized enterprises engaged in the market come about in a network habitat and rely heavily on their external networking (Musteen et al., 2010; Ciravegna et al., 2014). Moreover, having network relationships is essential for SMEs that have lack resources and capabilities to expand into foreign markets individually and survive in the fierce competition (Jeong, 2016). Hughes et al. (2019) stated external network affects a firm's performance in a manner of market-entry, market selection, market expansion, and market growth by accumulating knowledge, revealing opportunities, and expanding other networks. Nyuur et al. (2018) stated that domestic and international networks on SME internationalization phenomena play a significant role in contribution. The domestic networks are essential in the stage of preinternationalization of SMEs, whereas the international networks are re-opening internationalization or further developing the SMEs in the international market.

Even in the post-entry stage, the network influence positively on SMEs internationalization speed with the assistance of internal sources of knowledge, which can be self-learning, especially from trial-and-error and experiential efforts and external sources of knowledge which include peer networks, associations in the same industry, international customer, clients, and partners, and international relations developed through trade fairs and trade missions (Puthusserry et al., 2020). Many studies have found international networking is a cumulative process through which firms can identify business opportunities and support their entry into foreign markets (Ciravegna et al., 2014). The term "network" refers to the interconnected relationships among all actors involving in the market in this study. There are three primary interconnected networks; social, business, and institutional relations (Senik et al., 2011; Jin- Jung, 2016; Nyuur et al., 2018). 


\subsection{Social Network}

Previous research conducted in the field of network largely agreed that the social networks have a positive impact on SMEs internationalization performance (Ahimbisibwe et al., 2020) because it is the primary sources of information, knowledge, and fast learning, which are evolved based on personal relationships (Jeong, 2016). It can be derived from informal connected interaction among actors building on personal relationships, such as family, friends, colleagues, and employees (Zhang et al., 2016). The social networks also facilitate SMEs' decreasing transaction costs, risk, uncertainty associated with foreign market entry, and increased reliability and faith between partners. The reason why social networks may provide more information that cannot be collected through standardized market research to SME's owner/owner-managers.

Therefore, the trust-based personal ties seem to be more reliable and useful for SMEs' key decision-makers with limited resources and capabilities (Jin and Jung, 2016). In Asian settings, the social networks, also defined as "Guanxi," show positive influences on export, profitability, and sales performance, but positive impact declines when the competition in the market escalates (Jeong, 2016). This "Guanxi" influence is more often observed in the Chinese ethnic community, including in Taiwan, Hongkong, Singapore, Malaysia, and the Republic of China. It is constructed through family ties, the personal connection of the owners/owner-managers, trust, and cooperation with others.

\subsection{Business Network}

Many kinds of literature pointed out that business networks are studied more commonly than social and institutional networks (Costa et al., 2017). That is, a group of two or more interconnected business relationships, in which a mutual exchange of resources occurs, and each actor make a collective effort to achieve a common goal through cooperation between actors, including suppliers, customers, strategic partners, dealers, and competitors, etc. (Jin and Jung, 2016; Jeong, 2016). In this cooperation, market-specific knowledge is accumulated primarily through interaction with various actors in a particular foreign business network. Having a wide range of business ties with other actors helps SMEs make entry mode choices, determine the timing of international market entry, and offer an insight into marketing activities after entry.

Jin and Jung (2016) noticed that SMEs with a broad range of international business networks would have a greater chance of engaging with their business partners, promoting learning about the foreign markets. A study conducted among Korean SMEs argued that business networks' role is more significant than the social and institutional networks in increasing financial performance, performance satisfaction, and strategic performance in the international market (Santhosh, 2019). Jeong (2016) found that firms tend to hire internationally experienced managers and business 
consultants at the beginning of the internationalization process. Also, firms participate in trade fairs and exhibitions to expand and develop their business networking.

\subsection{Institutional Network}

As with social and business networks, the institutional networks also positively impact SMEs' internationalization process by lessening risks and facilitating decisions for expanding into new foreign markets (Vasa, 2003; Narooz and Child, 2017). The institutional network evolves between SMEs and numerous formal institutions, including the ministry of foreign trade and light industry, export promotion agencies, export supporting organizations, research and development institutions that support the exploration of foreign market opportunities and the internationalization process. Government support programs, government policies, international organizations assistance, innovation center activities, professional and research support institutions' works can indicate the institutional networks (Bencsik and Filep, 2020). As far, the role of institutional networks on SMEs internationalization, especially in developing countries, has not been explored well, despite previous studies highlighted that the institutional networks provide vital resources, such as market information, financial support, and business contacts, in a sustained way and lessen risks and increasing the speed of entries to new foreign markets, and lead to a positive attitude towards international entrepreneurship (Costa et al., 2017).

Figure 1. Framework of networks role on pre-and post-entry stage of firms

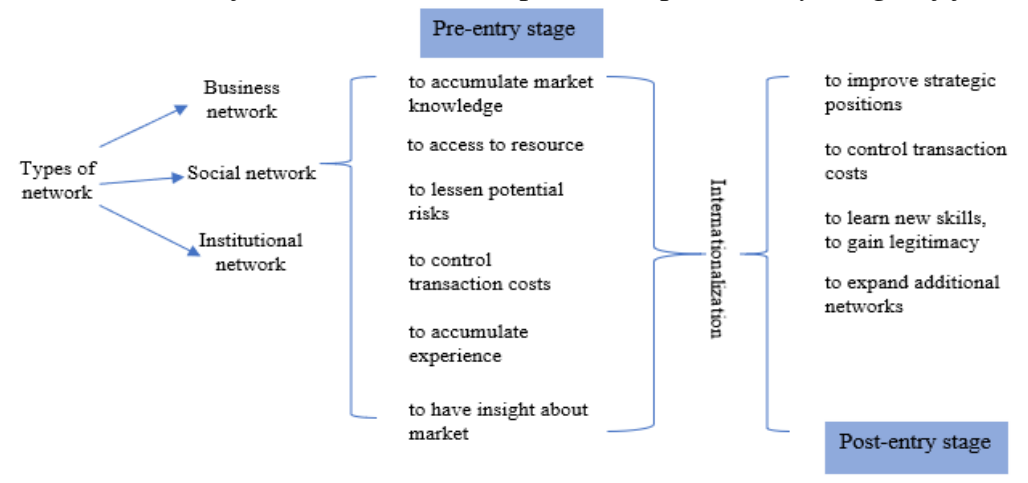

Source: The authors' edition on the basis of collected secondary data

\section{Material and Methods}

There is no single universally accepted criteria or definition for SME, small enterprises (SE), medium enterprises (ME) and each country have their classification and definition, in such a manner, we define an SME as an enterprise which has a high 
degree of managerial involvement of owners, or owner-managers who gradually become the founder of the firm in their daily operation and strategic management in general. In this study, networks are defined as established relationships that connect individuals, groups, and business organizations (Nyuur et al., 2018). The purpose of this study is to examine the role of network ties on SMEs ' internationalization process by comparing SMEs in three Asian developing countries. We made second hypotheses based on our research question in a broader context. First, network ties influence crucially on the SMEs internationalization process of the three selected countries. Second, among three types of networking, in China and Malaysia, the institutional network plays a crucial role compared to the social and business networks to the SMEs internationalization process.

In this paper, three questions are addressed: What are the primary roles of network ties on SMEs internationalization process for enterprises in developing countries? To what extent, the role of networking ties is the same in developed countries, and to what extent is it different from developed countries? Last, what are the main differences and similar characteristics between Malaysian, Chinese, and Mongolian SMEs, and their effective practices in their internationalization that should be adopted in Mongolia?

The study is descriptive and used secondary data as the primary source, valid and well-grounded documents, including research papers, publications, and books published by government agencies, individual researchers, and international organizations. The collected secondary data is reviewed systematically and determines the role of networking in internationalization in the result section. Also, the bibliographical review and comparative analysis have been done to draw implications for the policymakers, owner-managers, or managers of SMEs and researchers. Comparing three different countries SMEs networking formation and the role is the prominent uniqueness of this research.

\section{Results}

\subsection{Comparison of SMEs in Mongolia, China, and Malaysia's Internationalization}

In this section, the SME's networking degree in the three selected developing countries based on the existing literature are described: SMEs in Mongolia, China, and Malaysia. To provide a general perception of SMEs in three selected countries, we will briefly introduce them in Table 1. All data refer to between the years 20132017.

Table 1. Overview of the SMEs performance in the three selected countries

\begin{tabular}{|l|l|l|l|}
\hline & Malaysia & China & Mongolia \\
\hline Share of the total SMEs (\%) & $90 \%$ & $97.33 \%$ & $98 \%$ \\
\hline Contribution to GDP (\%) & $\geq 33 \%$ & $\geq 60 \%$ & $\leq 20 \%$ \\
\hline
\end{tabular}


The Role of Network Ties on SMEs Internationalization Process in the Developing

Countries/Emerging Markets: A Comparison between Mongolia, China, and Malaysia

\begin{tabular}{|l|l|l|l|}
\hline Contribution to employment (\%) & $60 \%$ & $82 \%$ & $67 \%$ \\
\hline Contribution to export (\%) & $18 \%$ & $36.6 \%$ & $2.3 \%$ \\
\hline
\end{tabular}

Source: The authors' edition on the basis of collected secondary data.

\subsection{Social Network and Business Network}

In the Chinese ethnic-dominated market, the social network, also known as Guanxi, is assumed to be critical for successful entrepreneurship and SME development, which is to be developed based on personal relationships such as work friends, business friends, and families, etc. In the Chinese language, Guanxi means that the special relationship between two people has with each other". The nature of "guanxi" somehow the same as the western term "networking or relationship marketing, but there is a slight difference in terms of types of relationship and impact. Fundamentally, Chinese SMEs heavily depend on their network, rather than professional agencies or management teams (also can be named a business network), in the decision-making process. As well, Chinese firms show a tendency to enter physically distant markets using their social networks than business or institutional networks.

Researchers stress that in some case, especially in developing or less developed countries, low institutional quality brings about such personal ties, which consider as vital for the SMEs success due to managers' networks act as a substitute for formal institutions in obtaining market information, interpreting regulations, securing resources, and enforcing contracts. The positive sides of building strong social network ties are listed as follows. First, SMEs can benefit from various information within their social networks. Second, SMEs can use it as crucial social capital to lessen risks and collect market information, followed by overcoming their sizerelated barriers through their social network.

Likely Chinese SMEs, the personal network (social network) is the second most influential factor to SMEs internationalization after business networks among Malaysian firms. Because both social and business networks are pivotal social capital for business creation and survival among SME managers or owner-managers.

Having summarized the result of studies conducted in Mongolia, both in the rural and urban area of Mongolia, micro and small-sized enterprises tend to heavily rely on the social network than business or institutional networks to obtain market-related knowledge and market access due to the low-level customer purchasing power, small and saturated market, and other tangible and intangible resources shortage. Along with dependency on just social networks individually, the opportunity to expand its business operation into a new geographical market might be dropped off because SMEs would potentially expand into a new international market with existing social and business networks. 
In China, Malaysia, and Mongolia, the specialized govt and non-govt agencies usually organize the arranged meeting sections among SMEs owners and managers to build business linkages between them and provide outsourcing opportunities. However, the efficiency of such kinds of conventions, events, and training has not been evaluated at every country level. There are specialized private firms in Malaysia and China that provide consultation services regarding export and import management for firms with low capabilities and resources entering the new market, which is a means to accelerate the firm's internationalization process. This experience should be adopted in Mongolia in order to support SMEs which try to internationalize. Moderate level influence for SMEs in China for their internationalization are found to be consistent with the result of Malaysia, but it seemed to low impact actions for Mongolian SMEs.

\subsection{Institutional Network}

There are two kinds of institutional influence on SMEs' development or emerging markets internationalization process from an institutional quality perspective. First, the escape view constrains the development of SMEs and pushes them to internationalize instead. The second view is fostering, encourage, and nurtures the development and internationalization of SMEs. Although the Chinese government tends to support and facilitate SMEs internationalization in a broader context, having a political network is considered the primary factor to benefit emerging markets like China and Malaysia.

The institutional network is crucial regarding establishing rightfulness for SMEs' innovative products in other markets that business networks cannot bring about. SMEs can also cooperate with successful organizations, including large state-owned (SOEs) companies with a well-settled international market, well-known educational or scientific institutions through institutional assistance. In general, the Chinese government stimulates SMEs by establishing financial funds, credit guarantee systems, consultant service, training, low-cost regulatory resources, including land, bank credits, and tax subsidiaries.

However, the low-regulatory resources are available for strong network connections with officials in charge or institutions. Also, the Chinese government offers more support and funding for large companies than SMEs, especially to the SOEs. Also, Chinese SMEs with strong political connections or networks are expected to acquire favorable government incentives, which may further open the door of internationalization. Therefore, we concluded that Chinese SMEs internationalize based on their internal capabilities, and institutional support may not be so useful and significant for them. In essence, only state-owned enterprises (SOEs) or firms with a more significant network in relevant institutions benefit from the policies taken to support SMEs internationalization. 
In Malaysia, the government strongly fortifies the SMEs development through its policy to create medium-scale SMEs that can compete in the global market. The government provides numerous supports to SMEs in Malaysia, such as financial assistance, tax incentives, business advisory assistance, and training. In total, nearly 200 programs within the last twenty years have been implemented by the government to enhance SMEs' access to finance in the manufacturing and service sectors, assisting SMEs in penetrating the export market or providing them with linkages exportoriented companies innovative and emerging information. Moreover, the venture capital funds, Rehabilitation Funds for Small and Mediums Industries, Debt Ventures, External Trade Development Corporation, National Entrepreneurs Agency, and Research and Development Center have been established. Like China, directed assistance does not reach the targeted SMEs because of a high level of bureaucracy and poor communication due to most of the SME programs are controlled by lengthy red tape, and the numbers of agencies involved are incredibly high. The involvement of various government agencies would likely create delays and redundancies in their functions and responsibilities, leading to inefficiencies and ineffectiveness.

Unlike China and Malaysia, both export share and the GDP contribution of SMEs are comparatively low in Mongolia. SMEs managers or owners highlighted that a less developed financial market, poor coordination of government institutional systems, and low customer purchasing power are the main constraints for their development. The correlation analysis, which was made to investigate the relationship between the Mongolian business environment indicators, shows that governance and legal indicators have the most significant impact on SME development. As noted, problems faced during Mongolian SMEs internationalization process are those which includes inadequate knowledge and information about export and import, limited network position in the international new market, less knowledge regarding making the contract, low limited networking which provides export and import information, low financial capability, limited resources, and low technical capacity. In table 2, the influence of types of networks on the SMEs internationalization process at the country level is summarized.

Table 2. Influence of types of networks on the SMEs internationalization process

\begin{tabular}{llll} 
& China & Malaysia & Mongolia \\
\hline Social network & Strong & Moderate & Moderate \\
\hline $\begin{array}{l}\text { Business } \\
\text { network }\end{array}$ & Moderate & Moderate & Weak \\
\hline $\begin{array}{l}\text { Institutional } \\
\text { network }\end{array}$ & Moderate & Weak & Weak \\
\hline
\end{tabular}

Source: Authors' edition on the basis of collected secondary data. 


\section{Conclusions and Implications}

This study concluded that institutional support mechanisms are substituted by the social and business networking ties in developing countries such as China, Malaysia, and Mongolia. However, SMEs in developing countries need to receive critical attention from the government to expand their operation in a new foreign market; there are some constraints to obtain this subsistence, such as bureaucracy and the need of having strong personal networking relationships with someone in charge of administration at relevant institutions. As a general rule, there is a tendency among SMEs owners and managers in which services and information that are beneficial for the creation and export of SMEs have been collected through personal connections rather than through widely available media channels in the developing countries. Personal connections are often required to enable institutional support or to sidestep the facing issues. While, in developed countries such as EU countries, Australia, and Japan, institutions play a significant role in creating conditions that stimulate and encourage SMEs internationalization in which SMEs managers or owners dealt with no problems at all to receive any services offering by the relevant institutions (Narooz and Child, 2017).

In a broader context, all types of external networking ties must be developed and sustained by the actors involved in the market, particularly between SMEs and the government's institutions, agencies, business associations, NGOs, and business partners such as MNEs embedded in their target market successfully. SMEs' chance to expand their operation individually in the international market is limited if there is a massive void between SMEs and encouraging institutional support mechanisms, including incentives, tax deduction, subsidies, training, and consultation. In such a manner, sometimes personal networking plays a replacement role for the appropriate supports which can speed up SME's internationalization process that should be provided by the institutions instead.

One implication of this research is that there is a tendency among SME managers and owners in developing countries that having a strong social relationship with all kinds of actors could bring development and accelerate the internationalization process. Therefore, institutional networking is some crucial roles neglect to a great extent. Instead, SMEs rely heavily on the information collected by the personal channels that might bring both pros and cons for their internationalization process.

Based on the collected data, both Chinese, Malaysian, and Mongolian government considers SMEs as an essential contributor to the economic growth and development and focus on SME development in their countries by improving the legal environment, enabling conditions of SMEs to obtain loans, investments, developing production, and introducing new technologies.

The second implication that should be taken on in Mongolia to create SMEs' conditions to thrive and internationalize is to establish private specialized firms or 
The Role of Network Ties on SMEs Internationalization Process in the Developing

Countries/Emerging Markets: A Comparison between Mongolia, China, and Malaysia

investment and export agencies to address SMEs' information and knowledge barriers. SMEs in Mongolia highlighted almost no networking ties to sell their products in foreign and domestic markets (geographically new market) due to financial constraints and lack of resources, limited access to financial means, and ancient technics. Creating specialized private firms which provide consultation service regarding export and import management for SMEs with low capabilities and resources entering the new market will accelerate the firm's internationalization process. In Mongolia, the number of successful large exporters is minimal, while the numbers and quality of the international firms minimal in China and Malaysia are comparable high.

Through specialized firms or agencies' full-fledged export promotion activities, SMEs would obtain proper assistance and guidance in their exporting activities without numerous actors' interventions. This kind of agency or firm's primary role is to provide non-financial and financial means to thrive SMEs, including studies on key target markets, marketing, consulting, and training for firms willing to export.

\section{References:}

Abdullah, N.A.H.N., Zain, S.N.M. 2011. The internationalization theory and Malaysian small medium enterprises (SMEs). International Journal of Trade, Economics and Finance, 2(4), 318.

Afsharghasemi, A., Zain, M., Sambasivan, M., Imm, S.N S. 2013. Market orientation, government regulation, competitive advantage, and internationalization of SMEs: A study in Malaysia. Journal of Business Administration Research, 2(2), 13.

Ahimbisibwe, G.M., Ntayi, J.M., Ngoma, M., Bakunda, G., Kabagambe, L.B. 2020. The internationalization of small to medium-sized enterprises: do all levels in international networking matter? Journal of Small Business and Enterprise Development, 27(5), 817-837. https://doi.org/10.1108/JSBED-09-2019-0313.

Arudchelvan, M., Wignaraja, G. 2015. SME internationalization through global value chains and free trade agreements: Malaysian evidence. ADBI Working Paper 515.

Tokyo: Asian Development Bank Institute. Retrieved from:

http://www.adbi.org/workingpaper/2015/02/16/6535.sme.internationalization.malaysia/.

Bencsik, A., Filep, B. 2020. Relationship Between Knowledge Management and Innovation. In: Bencsik, A. (ed). Knowledge Management Initiatives and Strategies in Small and Medium Enterprises, 531-554. IGI Global, USA.

Bowen, R. 2019. Motives to SME internationalization. Cross Cultural \& Strategic Management, 27(1), 51-74.

Chelliah, S., Sulaiman, M., Yusoff, Y.M. 2010. Internationalization and performance: Small and medium enterprises (SMEs) in Malaysia. International Journal of Business and Management, 5(6), 27.

Ciravegna, L., Lopez, L., Kundu, S. 2014. Country of origin and network effects on internationalization: A comparative study of SMEs from an emerging and developed economy. Journal of Business Research, 67(5), 916-923. 
Costa, E., Soares, A.L., de Sousa, J.P. 2017. Institutional networks for supporting the internationalisation of SMEs: the case of industrial business associations. Journal of Business \& Industrial Marketing, 32(8), 1182-1202.

Deng, P., Zhang, S. 2018. Institutional quality and internationalization of emerging market firms: Focusing on Chinese SMEs. Journal of Business Research, 92, 279-289.

Doojav, G.O., Luvsannyam, D., Sukhbaatar, B., Sodnomdarjaa, B., Otgonbat, T., Batmunkh, K., Gantumur, M., Enkh-Amgalan, E. 2020. Development and Access to Finance of Small and Medium-Sized Enterprises in Mongolia. In: Ordoñez de Pablos, P. Zhang, X., Chui, K. T. (eds). Innovative Management and Business Practices in Asia. IGI Global, 265-294.

Ganbold, M. 2016. The impact of the small and medium enterprise support programmes on the livelihoods of micro-entrepreneurs using sustainable livelihood framework: a case study of Enterprise Mongolia Project Phase 2 by United Nations Development Programme in Mongolia. PhD thesis, Massey University, Palmerston North, New Zealand.

Gardó, T.F., García, H.C., Descals, A.M. 2015. Internationalization of SME retailer: barriers and the role of public support organizations. International Journal of Retail \& Distribution Management, 43,183200.

Hao, J., Li, C., Yuan, R., Ahmed, M., Khan, M.A., Oláh, J. 2020. The Influence of the Knowledge-Based Network Structure Hole on Enterprise Innovation Performance: The Threshold Effect of R\&D Investment Intensity. Sustainability, 12(15) paper 6155. https://doi.org/10.3390/su12156155.

Hashim, F. 2015. SMEs' impediments and developments in the internationalization process: Malaysian experiences. World Journal of Entrepreneurship, Management and Sustainable Development, 11(2), 100-119.

He, C., Baranchenko, Y., Lin, Z., Szarucki, M., Yukhanaev, A. 2020. From global mindset to international opportunities: the internationalization of Chinese SMEs. Journal of business economics and management, 21(4), 967-986.

Hughes, M., Cesinger, B., Cheng, C.F., Schuessler, F., Kraus, S. 2019. A configurational analysis of network and knowledge variables explaining Born Globals' and late internationalizing SMEs' international performance. Industrial Marketing Management, 80, 172-187.

Ishtiaq, A., Oláh, J., Popp, J., Domicián, M. 2018. Does Business Group Affiliation Matter for Superior Performance? Evidence from Pakistan. Sustainability, 10(9), 3060.

Jeong, S.W. 2016. Types of foreign networks and internationalization performance of Korean SMEs. Multinational Business Review, 24(1), 47-61.

Jin, B., Jung, S. 2016. Toward a deeper understanding of the roles of personal and business networks and market knowledge in SMEs' international performance. Journal of Small Business and Enterprise Development, 23(3), 812-830. https://doi.org/10.1108/JSBED-08-2015-0104.

Karácsony, P. 2020. The impact of the coronavirus (COVID-19) on the employment characteristics of Hungarian SMEs. Virgil Madgearu Review of Economic Studies and Research, 13(2), 105-117.

Kozár L. - Neszmélyi G. (2017): Hungarian Endeavours for the Enhancement of Economic Relations in Southeast Asia Focusing on a New Partnership with Vietnam. Apstract - Applied Studies in Agribusiness and Commerce 11 : 3-4 pp. 5-12. https://doi.org/10.19041\%2FAPSTRACT\%2F2017\%2F3-4\%2F1

Lin, S., Mercier-Suissa, C., Salloum, C. 2016. The Chinese born globals of the Zhejiang Province: A study on the key factors for their rapid internationalization. Journal of International Entrepreneurship, 14(1), 75-95. 
The Role of Network Ties on SMEs Internationalization Process in the Developing

Countries/Emerging Markets: A Comparison between Mongolia, China, and Malaysia

Lis, B., Nienstedt, H.W., Proner, P., Yalazi, G., Mauch, A. 2012. SMEs Going Global: A Comparison of the Internationalization Strategies of Publishers and Online Social Networks, International Review of Management and Marketing, 2(1), 1-9.

Lkhagvasuren, T. 2014. Marketing of small and medium sized enterprises in Mongolia. International Journal of Technology Engagements and Emerging Engineering Research, 2(5), 33.

Lloyd-Reason, L., Mughan, T. 2002. Strategies for internationalization within SMEs: the key role of the owner-manager. Journal of small business and enterprise development, 9(2), 120-129.

Magda, R., Dhanashree, K. 2017. Factors Influencing Entrepreneurship in Rural Communities: An Overview about Indian Scenario. Annals of The Polish Association of Agricultural and Agribusiness Economists, 19(4), 28-33.

Mongolian National Chamber of Commerce Chamber. 2017. A study of Mongolian Business Environments.

Musteen, M., Francis, J., Datta, D.K. 2010. The influence of international networks on internationalization speed and performance: A study of Czech SMEs. Journal of World Business, 45(3), 197-205.

Narain, S. 2013. Using ICT and knowledge management to facilitate SMEs participation in regional and global supply chains with focus on Bangladesh, Bhutan, Mongolia and Timor-Leste. UN-ESCAP, Dhaka.

Narooz, R., Child, J. 2017. Networking responses to different levels of institutional void: A comparison of internationalizing SMEs in Egypt and the UK. International Business Review, 26(4), 683-696.

Neszmélyi, G. (2002): The Main Characteristics of Mongolian and Korean Economic Development, Focusing on Agriculture. In: Gervers, Michael; Schlepp, Wayne (eds.) Continuity and Change in Central and Inner Asia: Central and Inner Asian Seminar (2000-2001: University of Toronto). Toronto, Canada: Asian Institute of Technology (2002) 361 p. pp. 113-126.

Nyuur, R.B., Brecic, R., Debrah, Y.A. 2018. SME international innovation and strategic adaptiveness: The role of domestic network density, centrality and informality. International Marketing Review, 35(2), 280-300. https://doi.org/10.1108/IMR11-2015-0239.

Puthusserry, P., Khan, Z., Knight, G., Miller, K. 2020. How do rapidly internationalizing SMEs learn? Exploring the link between network relationships, learning approaches and post-entry growth of rapidly Internationalizing SMEs from Emerging Markets. Management International Review, 60(4), 515-542.

Sandberg, S., Jansson, H. 2014. Collective internationalization-a new take off route for SMEs from China. Journal of Asia Business Studies, (8), 29-42.

Santhosh, C. 2019. Impact of determinants on early internationalization. Journal of Engineering, Design and Technology, 17(5), 1018-1034. https://doi.org/10.1108/JEDT-01-2019-0001.

Senik, Z.C., Isa, R.M., Scott-Ladd, B., Lanny, E. 2010. Influential factors for SME internationalization: Evidence from Malaysia. International Journal of Economics and Management, 4(2), 285-304.

Senik, Z.C., Scott-Ladd, B., Entrekin, L., Adham, K.A. 2011. Networking and internationalization of SMEs in emerging economies. Journal of International Entrepreneurship, 9(4), 259-281. 
Sokil, O., Zhuk, V., Vasa, L.. 2018. Integral assessment of the sustainable development of agriculture in Ukraine. Economic Annals-XXI 170 (3-4) pp. 15-21.

Solongo, G. 2017. Financial Resources Management for SMES of Mongolia. International Business Research, 10(6), 145-163.

Torkkeli, L., Puumalainen, K., Saarenketo, S., Kuivalainen, O. 2012. The effect of network competence and environmental hostility on the internationalization of SMEs. Journal of International Entrepreneurship, 10(1), 25-49.

Tuul, O., Bing, S.J. 2019. Employee training in small and medium-sized enterprises in Mongolia. Proceedings of the Mongolian Academy of Sciences, 59(1), 75-84. https://doi.org/10.5564/pmas.v59i1.1140.

Vasa, L. 2003. A magyar agrárpolitika helyzete és az Európai integrációval kapcsolatos kihívások (The situation of the Hungarian agricultural policy and the challenges of European integration, in Hungarian). Politikai Elemzések III (2). pp. 29-56.

Vásáry, M., Kránitz, L., Vasa, L., Baranyai, Z. 2013. Versenyképességi vizsgálatok a visegrádi országok közötti agrárkereskedelemben (Analysi of competitiveness of agro-trade among Visegrad Countries, in Hungarian). Gazdálkodás, 57 (6), 544558.

Yener, M., Doğruoğlu, B., Ergun, S. 2014. Challenges of Internationalization for SMEs and Overcoming these Challenges: A case study from Turkey. Procedia-Social and Behavioral Sciences, 150, 2-11.

Zhang, X., Ma, X., Wang, Y., Li, X., Huo, D. 2016. What drives the internationalization of Chinese SMEs? The joint effects of international entrepreneurship characteristics, network ties, and firm ownership. International Business Review, 25(2), 522-534. 